\title{
Ethnic Relations: A Study of Hausa Community in Ogbomoso, Nigeria - (1924 - 1967)
}

\author{
Abdulwahab Tijani \\ Department of General Studies, Ladoke Akintola University of Technology \\ Ogbomoso, Nigeria \\ E-mail: immamtijani@yahoo.com
}

KEYWORDS Ethnic groups; relations; contact; violent

\begin{abstract}
This work is a study of the inter ethnic relations between the Hausa and Yoruba ethnic groups in Ogbomoso. The main objective of the work is to study the phenomenon of inter ethnic contact between the Hausa and Yoruba ethnic groups in Ogbomoso. Inter ethnic contact could lead to conflict or integration. In this work, studies have shown that, unlike the process of the establishment of Hausa community Ibadan, the establishment of Hausa Community in Ogbomoso did not experience violent inter ethnic conflicts. This was due to the peculiar nature of the inter-ethnic relations between the two groups as well as longer period of contact.
\end{abstract}

\section{INTRODUCTION}

Inter-group relations is assuming an important area of study in Nigerian historiography. In particular, reference to Yorubaland, while a lot of work has been done on inter-group relations between the various Yoruba groups not much has been done on the important groups that settled among them. This work is a study of the Hausa Community in Ogbomoso between 1924 when Sabo was established for the Hausa Community in Ogbomoso, and 1967 which was a watershed in the history of inter-group relations in Nigeria. Ogbomoso presents a special case study due to its proximity to the north and the long contact between Ogbomoso indigenes with the Hausa, both in Yorubaland and in Hausaland.

This study is intended to understand the consequences of the migration and contact between the Hausa people and their Yoruba hosts in Ogbomoso. This is based on the premise that "social interaction between people of diverse ethnic and cultural backgrounds could lead to integration or disintegration (conflict) (Tijani, 2002). The phenomenon of inter ethnic conflicts has been the bane of modern nations. Some writers believe that the problem arise from contact between people that have linguistic, cultural and ethnic diversity. They belief that diversity of culture is inherently the basis of inter-ethnic conflict. For instance. Professor Onwuaejeogwu observes that:

The fact that there are over 300 ethnic groups in Nigeria makes it a unique and grotesque instance of a country that suffers from "hyper-ethnic instability syndrome" (Onwuejewu, M. R., 1987).

Similarly, Professor O' Connel asserts that:

there is 'inevitability of instability' in Africa's artificially created, and ethnically diversed modern nations (O' Connel, 1967).

However, history of inter-ethnic contact in pre-colonial Nigeria have shown that diversity of culture and ethnicity have not always led to conflicts. People had found common grounds to resolve their groups differences when they came into contact with one another. This has been discussed by O. Ikime (1985). Tijani, (1999, 2002). Similarly, Nnoli (1978) has rightly shown that it is not inter-ethnic contact between groups that breeds conflicts, rather it is the extent of competing claims that are associated with the economic and political problems of modern nation states. (Nnoli, 1978).

Our interest in this paper is not on causes and impacts of inter-ethnic conflicts especially in migrant settlements in Nigeria. Violent interethnic conflicts in Kano, Shagamu, Kaduna, Warri, Lagos, Bauchi etc. have drawn the attention of researchers. The concern of this paper is a direct contrast from these preoccupations of researchers on inter-ethnic relations in Nigeria. It is concerned about the social and historical factors that had sustained peaceful and harmonious inter-ethnic relations between 'hosts' and 'strangers' in Nigerian cities, especially Ogbomoso. Particularly, the factors that led to peaceful co-existence between the Hausa people and their Yoruba hosts in Ogbomoso. This has been largely neglected by 
writers or probably unnoticed. In view of the above, this work shall explore this area with the objective of turning search light on the significance and potentials of learning from historical experience in peaceful inter-ethnic co-existence. This has been expressed by Stanfield (1996) that:

As much as we know about how ethnically different people do no get along well, we know virtually nothing about the converse ethnically different people living together in sustaining peace.

There might be a little of an over-statement in this, but the fact remains that it is necessary that we research into the vast field of the institutional and diplomatic history and understand the factors that had sustained inter-group peaceful co-existence between Nigerian diversed ethnic groups in some of our cities. This is not an assumption that human society can become completely devoid of conflict - a situation which Zarman (1998 : 3) likened to "a different world beyond the skies". This is rather Utopian. Rather we view inter-ethnic relations as containing both conflictual and integrative elements. Schermerhon (1970) rightly view inter-group relations:

As a continuing process rather than a state of being, relative rather than all embracing, corrective rather than self-subsistent, a matter of degree rather than an all - or none phenomenon, and correlations with conflict rather than a displacement of conflict.

Consequently, we view the inter-ethnic relations between the Hausa people and their Yoruba hosts as containing more interactive elements than conflicts especially in the absence of violent conflicts.

Migration forms one of the major ways of establishing inter-ethnic contact. Various works have been produced on internal migration in Nigeria. One of such works by Makinwa captures the major findings of scholars on internal migrations in Nigeria. There are two main perspectives of the theories of migration: the economic and the non-economic determinants of migration. First she pointed out that migration is usually from low income areas with few job opportunities with the objective of improving the status and economic well being of the migrants. Secondly, the non-economic factors affect the decision to migrate such as "means of transport, presence of relatives, friends and/or co-villagers at destination, ethnic compatibility and residual environmental factors at both origin and destination"
(Makinwa, 1981). Migration could also be taken for social, religious or political reasons. In this study, the main factor that led to the migration of Hausa people in the pre-colonial period into Yorubaland generally was trade and commerce. There were other factors that motivated their migration. Such as the spread and propagation of the religion of Islam. This has been well documented by Mahdi Adamu (1978), T.G.O. Gbadamosi (1975) and Love Joy (N.D.)

\section{THE HAUSA CONTACT WITH YORUBA LAND}

Contact between the Hausa and their Yoruba hosts in Ogbomoso was primarily based on economic motives in the form of inter regional trade. The most important trade partners of the Hausa in the pre-colonial period were the Yoruba, the Asante, the Junkun and Nupe peoples. Each of these people had for a long time developed its own imperial administrative system. The peoples had attained high level of civilization such that they had as much home-made products to exchange with the Hausa traders as they would buy from them. Another important factor that provided sufficient basis for the development of commercial relationships between Yorubaland and Hausaland was the geographical locations of their countries. Hausaland is strategically located at the end of one of the trans-Saharan trade routes, it continuously received variety of valuable goods of oriental origin through North Africa, which the Hausa traders reexported to the south. On the other hand, the Yoruba traders controlled the coastal trade with the European and re-exported European goods into Hausaland. Each of them had established middlemen trading positions in such goods to which they had direct access (Tijani, 2003).

The main important commodities of trade imported by Yoruba traders through the northern traders were horses, clothes, and slaves. These northern traders were mainly Hausa, Nupe and Baribari. In the $17^{\text {th }}$ and $18^{\text {th }}$ Centuries when Oyo placed emphasis on calvary for her military strength, she had to depend on large-scale importation of big horses from the north, to reinforce the Kuru Horses bred in Guinea-Savannah belt (Tijani, 2003).

In the $18^{\text {th }}$ Century, when Old Oyo Kingdom was at the peak of its power, she occupied a middle man position on the trade route between Hausaland and Gonja on one hand and between the Southern 
forest parts of Yorubaland and Hausaland on the other. Oyo Kingdom collected tools on caravans that passed through its territory to Gonja. Secondly, she took part in the kolanut trade from this southern forest region. The central Provinces of Oyo Kingdom were located in the Savannah region which was in suitable for the production of kola. On the other hand, the forest region of Egba, Egbado, Awori Ijebu-Ife, Ijesa and Ekiti was favourable to the production of kolanuts. Oyo Yoruba exchanged acuminata (Kola) nuts, salts, and other items mentioned earlier for horses, potash and textiles. (Tijani, A. Ibid).

Before the mid $19^{\text {th }}$ Century, there were two main areas of trade contact between Yoruba and Hausa trades. The first area was along the Northern edge of the forest including such Yoruba towns as the Old Oyo capital, Oyo-Ile, Kishi, Saki, Igboho, Ikoyi, Ogbomoso, Ilorin and Rakka (an important trading station on the River Niger). The second line of contact was along the coast where Badagry and Lagos provided the mainly centres of trade. However, in the course of the $19^{\text {th }}$ century, the main centre of trade of the Yoruba people shifted from the Northern edge of the forest region due to the fall of the Old Oyo capital. This provided the Hausa people the opportunity to operate in the heartland of Yorubaland, especially in Ibadan and Abeokuta. Some of the Hausa traders were involved in livestock trade. By the early nineteenth century, the Hausa traders had settled in midst Yoruba people in the indigenous quarters of the Yoruba towns. 'This first set of Hausa settlers in Yoruba communities were later joined by their other kinsmen, like those that left the Gold Coast in the nineteenth century as a result of the harsh economic policies in the area (Albert, I.O., N.D.).

Other Hausa migrants were the demobilised soldiers after the second world war, there were also the roving Islamic scholars and students; the petty traders known as Yan Koli and the seasonal labour migrants known as Yan Cin rani, (Tijani, 2003).

\section{THE HAUSA COMMUNITY IN OGBOMOSO}

Before the beginning of the $20^{\text {th }}$ Century, migrants from Hausaland settled within the indigenous host quarters in Ogbomoso, especially in Isale Afon, Taraa, and Oja-Jagun quarters. They settled as tenants with the Yoruba landlords many of whom were their trade partners. However, the population of the Hausa migrants increased at the beginning of the $20^{\text {th }}$ Century in Yoruba towns. This was due to the shift in the major trade routes from Gonja - Jegga - Sokoto and Kano routes, to Ibadan-OgbomosoIlorin-Kano routes and other routes passing through Yorubaland.

In Ogbomoso, in 1890, the Hausa migrants requested for farmlands, Soun Laoye who was the Baale (monarch) of Ogbomoso at that period allocated a farmland to them which later developed into Gambari town. Many of the Hausa people settled on their farmland, gradually it developed into an Hausa community. This attracted other Hausa people from Ibadan, Ilorin, Abeokuta and others from the surrounding tons and villages of Ogbomoso.

Yoruba traders brought their wares, usually fruits and locally produced soap, sponges and so on, they would say "Mon lo si Ilu awon Gambari"; i.e. "I am going to the town of Gambari (Hausa people)". Eventually the place became known as Gambari.

After the establishment of Gambari as a settlement by 1898 the farmland allocated to the Hausa people became insufficient as the population of the Hausa migrants kept on increasing, hence they requested the Soun for the extension of the area allocated to them. Therefore, the farmland was extended to the present site of Abuduka Village. The younger brother of the Hausa leader of Gambari Sarkin Gambari Jubril had a quarrel with the Sari in 1899. He had established his farm at Abuduka, in annoyance he left for his farm and refused to return to Gambari. After three days the 'Fadawa' (Palace Officials) of Sarkin Gambari sought the consent of the Sarkin to go in search of his younger brother. They went to his farm and asked him to return to Gambari, he did, but he returned to his farm after two days. He told them that he would always return to Gambari on Fridays, but he should be allowed to remain on his farm. He said "Abuduka na Allah ne"; i.e. "Everything belong to Allah". Since then the farm site which has since become a village has been referred to as Abuduka (Tijani, 2003).

\section{Establishment of Sabo - Ogbomoso}

The establishment of Sabo community in Ogbomoso was harmonious compared to the first Sabo community in Yorubaland, i.e. Ibadan. One may question the reasons for this differences, 
while the establishment of Sabo Ibadan experienced fierce trade competitions and even the threat of expulsion of Hausa traders by Ibadan indigenes. In Ogbomoso the Hausa not only requested for a land to settle but also a farmland. We could attribute this to the nature of trade relations between the Ibadan people and Hausa traders.

The attempt to monopolise kolanut trade by the Hausa traders during the last decade of the nineteenth century was the main grouse that strained the relationship between the Hausa traders and Ibadan indigenes. While Ogbomoso is located in Guinea Savannah region, where kolanut was not grown but bought from the Southern ;parts of Yorubaland. Therefore, there was no serious threat to the economy of Ogbomoso traders.

Secondly, Ogbomoso is located closer to Hausaland, it had been one of the entrypots of Hausa traders on their route to Gonja in Volta region since about the seventeenth century. Therefore there had been longer period of contact between the Hausa traders and Ogbomoso people. Similarly, Ogbomoso traders founded trading communities in many parts of Hausaland especially in Kano for over three hundred years. (Tijani 2003).

The main issue in the establishment of Sabo Ogbomoso was cultural incompatibilities, which was a garb for the Hausa economic interests. This was because perior to the establishment of Sabo quarters in Ogbomoso, the cattle market had been established at the outskirt of the town, towards the north-east at a place now known as Odokoto, the cattle as in other Yoruba towns was called Sango or Zango. The Zango market was headed by Sarkin Zango i.e. The head of livestock market. There was also the Parakoyi who served as intermediary in commercial transactions. Those who held the offices were often Yoruba people who had travelled to Hausaland and understood Hausa or had learnt the language after long years of trading with the Hausa people, while they were learning the Quran and the religion of Islam. One of the earliest Sarkin Zango in Ogbomoso was Adetutu Adebunola (d. 1931). There was also the Iyalaje (the Female leader of commercial activities). These market officials collected royalties on trade transactions and remit part of it to the Yoruba traditional ruler of Ogbomoso (the Baale or Soun of Ogbomoso).

In about 1920, Soun Bello Afolabi Oyewumi I (the traditional ruler of Ogbomoso) shifted the cattle market (Zango) from Odo Koto area to a new site north-western part of the town. It was said that he wanted the cattle market located closer to his palace; as it was the general practice in those days whereby markets were located near the palace. Throughout Yorubaland we have 'Oja Oba' the King's market.

The Hausa community in Ogbomoso, requested for a piece of land on which they would establish a quarter, they wanted it to be close to the cattle market. This is the general practice of Hausa people in diaspora. This was because they wanted to get closer to the centres of inter-regional market, although such request was made under the ideology of cultural in compatibility. Consequently, in 1924, Soun Bello Afolabi Oyewumi Ajagungbade I resettled them at a location north of the new Sango named Sabo.

The establishment of Sabo quarters assisted the transfer of leadership from Yoruba market officials to the Hausa traders. The Hausa commission agents emerged to mediate in trade matters between buyers and sellers. By posing to be more trustworthy than his Yoruba counterparts, the Hausa commission agent or 'Yan Kwanisho' gained more confidence of his kinsmen from the North who came to sell cattle. These agents received commission, from the buyer cattle Laada in Hausa. This was part of Hausa trade customs found in Hausaland. Similarly, Hausa landlords emerged to house merchants from Hausaland.

The establish rent of Sabo meant that the Yoruba commission agents and Landlords with whom the Hausa traders and dealers had been lodging were edged out of the control of the interregional trade between the Hausa and Yoruba traders. The Hausa people began to collect, not only the commission Laada but also the rent from lodging the Hausa traders. Brokers as well as fees that were paid on keeping cattle within enclosures on their land were also collected by the Hausa people. The issue of Laada led to conflicts between the Yoruba and Hausa people in different parts of Yorubaland, especially in Ibadan. In Ogbomoso there was not such serious conflicts since the Soun of Ogbomoso was involved in the appointment of those market officials that collected Laada.

Prior to the establishment of Sabo in Ogbomoso the Hausa leader was referred to as Sarkin Pawa i.e. the head of butchers. After the movement of Zango to the North western outskirt 
of the town. In 1920. Soun Bello Afolabi Oyewumi appointed Mallam Nahero, a migrant cattle trader from Kano as Sarkin Pawa and as Sarkin Hausawa. Soun was said to have complained about the gifts from the Sule of Animal livestock hence he removed Adetutu as Sarkin Zango and appointed Okewole to replace him.

Generally, the choice of Sarkin Hausawa was done by choosing a consensus candidate by the elders of the Sabo community. The choice would then be presented to the indigenous traditional ruler for approval. Secondly, in the choice of a candidate. Preference is given to those who had settled for longer periods and had become business magnates. Such persons must have acquired influences, honour and recognition as business landlords.

While in Ibadan, the post of Sarkin Pawa (Head of Butchers) and Sarkin Hausawa (Leader of Hausa Community) led to protracted conflicts which polarised the leadership of Sabo community between 1930 and 1935. This conflict was between Sarkin Hausawa Umar and Sarkin Pawa Shuaibu over the collection of trade commission (Laada). It was so serious that it involved the Olubadan-in-Council and the British District Officer both taking side with Umar. In Ogbomoso although in 1922, the post of Sarkin Hausawa (Leader of Hausa Community) became a tussle it did not experience the magnitude of the conflict in Ibadan (Albert, 1994).

In 1922, the post of Sarkin Hausawa became a tussle between Mallam Nahero and Mallam Garba Na Embaloje, both of whom were cattle traders from Kano. Garba was eventually chosen to replace Naheoro. Garba then became the head fo butchers and heat of Hausa community, i.e. Sarkin Pawa and Sarkin Hausawa.

These conflicts among the Hausa cattle dealers for the post of Sarkin Pawa and Sarkin Hausawa, represents the connection between trade matters and politics. The Sarkin Pawa as the head of butchers was also the leader of all Hausa people at this period. His position was powerful and this enhanced his business. By virtue of his position he became the most eligible and trustworthy business landlord. This would attract lots of commission from the business tenants. He was also entitle to part of the royalties collected on the sale of cattle. All these in addition to the honour and prestige that the office commanded made it worthwhile for the rich Hausa leaders to be in conflict over the post of Sarkin Pawa.
The establishment of Sabo necessitated the appointment of Sarkin Hausawa (Head of Hausa community). This was because the new community needed a more powerful leader, because the title Sarkin Hausawa (the leader of Hausa people) was more powerful and the title Sarkin Hausawa (the leader of Hausa people) was more encompassing than Sarkin Pawa (Head of Butchers) (Tijani, 2003).

It was essential for the Hausa Landlords to emphasize his 'Hausa-ness' to gain the trust of Hausa Northern dealers, who would entrust their goods and money only into the hands of his kinsmen in a 'strange land', who live in a highly stable and organized Hausa community. This community comprised mainly those who had been residing in various compounds within the indigenous parts of Ogbomoso before the establishment of Sabo, when they moved to Sabo they became the trusted business Landlords of Hausa and Fulani cattle dealer. There was the need for trade transactions in an atmosphere of trust, especially where credit facilities were required. This is due to the fact that cattle sellers sold on credit to Yoruba butchers and there were no documentation of the transactions, there were no banks or official courts to intervene in the business (Cohen, 1969). In Sabo Ogbomoso, the few business landlords up to the 1950s were the Sarkin Sabo Alhaji Adulsalami who owned about five big houses that were used to accommodate his business associates and staff. There was also Alhaji Danjuma, Alhaji Muhammadu Mai Dogon Gida who was the Sarkin Gambari up till 1952 and Abdullahi Nahero the son of the first Sarkin Hausawa (the leader of the Hausa) of Sabo, Ogbomoso. These were cattle dealers. The main business activity in Sabo then was cattle trade as it was not located in the forest region where kola was abundant. However, a lot of kolanut business was carried out as well. The business landlords sent their clients to towns in the forest region to purchase the nuts (Tijani, 2003).

In both cattle and kolanut trades, the dealers were not charged by the landlord for accommodation or for food. These expenses were usually covered by part of the commission (Laada) which he receives from conducting the business of his dealers. The dealers deposits his money with his business landlord for safety, gives him commissions for his services and rely on him as surety for credit facilities granted the 
Yoruba butchers. In the livestock trade whereby nearly all sale were on credit, the landlord as the guarantor would have to repay money to dealers in case of default on the part of buyers (Cohen, 1969). For instance Alhaji Salami Onidaba recalled that buyers who used to come from surrounding towns of Ogbomoso to buy livestock in Zango, Ogbomoso, would purchase five cattle and paid for two, but they at times default in paying the balance (Tijani, 2003).

\section{THE EFFECTS OF NATIONAL POLITICS ON INTERGROUP RELATION IN SABO COMMUNITY}

The rise of party politics threatened the unity autonomy and exclusiveness of Sabo Communities in Yorubaland. This was due to the activities of the political party and the rise in importance of politicians and nationalists as leaders of thought and action. The Richard's Constitution of 1946 led to the regionalisation of Nigeria. The regions were demarcated into three; each of them was dominated by the three major ethnic groups, the Hausa in the North, Yoruba in the South-West and Ibo in the South-East. The McPherson Constitution of 1951 preserved the regions and even increased their power.

Consequently, the Action Group Part (A.G) galvanized Yoruba people into action to presents a united Yoruba front in the ethic politics of the late colonial period. The National Council of Nigeria Citizens (NCNC) did the same for the Ibo people, while the Northern Peoples' Congress (NPC) rallies the Northern peoples into a United block to fight the political interests of Northern Nigerian Peoples (Tijani, 2003).

The two southern parties, the Action Group (A.G.) and the National Council of Nigerian Citizens (NCNC), hoped to gain the support of the Hausa people in Sabo communities in Yorubaland for their electoral victory and the Western Regional Level. This was important if we consider that the population of Hausa people in Western Region by 1952 Census was 41,000. This figure did not include those who did not register themselves either because they were afraid of taxation or because they were temporary migrants. These political parties established branches in Sabo quarters, condemned tribalism and declared that Sabo residents were no longer "Native strangers" under the New Nation-State but equal citizens (Albert, 1994).
Generally, leadership of people in the country passed from the traditional rulers to the politicians and nationalists. Membership and loyalty to the political parties impaired the former loyalty given to traditional ruler sin the country. Loyalty given to Sabo Chiefs were equally affected. This threatened the distinctiveness and autonomy of Sabo communities in Yoruba towns. Because of the function of Sabo chiefs in the organisation of the communities, any threat to the authority of the chiefs of Sabo quarters was indeed a threat to the very continuity and distinctiveness of the Sabo communities. The leaders of these parties were now in the forefront agitations for the people (Cohen, 1969). Initially, many members of the Sabo Communities in Yoruba towns joined the NPC, which they saw as representing Hausa-Fulani interests within the Nation-State. When Aminu Kano formed the Northern Elements Progressive Union NEPU, many of the Kano and Katsina cattle dealers and Kolanut traders moved into NEPU, (Tijani, 2003).

However, as a result of the vagaries of Nigerian politics, the Hausa people in these Sabo communities soon learnt that in the circumstances they found themselves it was in the best of their interest to support Southern Parties especially the Action Group Party. They also learnt that their votes for the NPC would not have any significant electoral consequences in Western Regional Elections as NPC candidate would never have enough votes to win regional elections. (Cohen, 1969).

Significantly, the Hausa cattle dealers were apprehensive about the thousands of pounds worth of cattle, which they sold on credit to Yoruba butchers. Therefore, a good number of them joined the Action Group Party, while some of them joined the NCNC. In the early 1950's the NCNC was serious rival to the Action Group in the West (Albert, 1994).

In Ogbomoso, many of the Hausa cattle dealers also joined the Action Group party especially because the party was growing stronger and stronger in the West. The presence of Ladoke Akintola in the Leadership of the Action Group attracted many Hausa people to the party in Ogbomoso, his place of birth. Akintola had grown up in the North and he spoke fluent Hausa. He was said to have been a powerful orator who brought many Hausa people into the party in Ogbomoso, Ede, Oyo and Osogbo (Tijani, 2003). 
Politics in Sabo Ogbomoso did not go without its vagaries, for instance, when Mallam Muhammadu Isa, the Sarkin Gambari i.e. (the Hausa Leader fo Gambari settlement) refused to leave the NCNC for the Action Group in the 1950s, he was removed by Soun Oyetunde A. and inhis stead, Alhaji Mhammadu Maidogon Gida, his younger brother was made to replace him in 1952, because the latter was in the forefront of the Action Group in Ogbomoso (Tijani, 2003).

The rise of party politics had effects on the social structure of Sabo community in Ogbomoso. First, it brought Yoruba and Hausa people together in political activities and social interactions, such as meetings, negotiations, campaigns etc. as it de-emphasized ethnicity. For example, the Action Group produced some Hausa Councillors in Sabo Ogbomoso, such as Alhaji Kulumo Bicci and Alhaji Muhammadu Shekarau in 1962 (Tijani, 2003).

However, the confused state of politics in Western Region in the past 1960 era had its effects on party activities within the Sabo Community. There was rivalry not only between the Action Group and the NCNC but also within the Action Group between the leaders of the party, i.e. Chief Awolowo and Ladoke Akintola who was the deputy leader. The crises came to a head in 1962 when a state of emergency was declared in the West. Chief Awolowo, the Action Group Leader went into detention while Akintola returned as the Premier of Western Region. He formed a new party, the United Peoples' Party UPP.

Therefore by 1963 there were three major political parties contending for power in Western Region as well as in the Sabo communities of Yoruba towns namely, the NCNC, the Action Group and the newly formed United Peoples' Party (UPP). The Hausa people who part-took in partisan politics in these Sabo communities were mostly careful in aligning with the strongest party in the immediate environments. While those in Ibadan had double dealings between the Akintola and factions, those in Sabo Ogbomoso joined the newly formed Akintola's UPP. Ogbomoso been the birth place of Akintola. By 1964 when the UPP joined the NPC and others in the Nigerian National Alliance, NNA, while the Action Group, NCNC, NEPU and Newly formed the United Progressive Grand Alliance, the Hausa residents of Sabo Ogbomoso felt secured from the Political violence engendered by the formation of the two Grand Alliances. The death of Akintola and the Leaders of NPC i.e. Sir Ahmadu Bello and Sir Tafawa Balewa in the January 1966 coup brought a sense of mutual lost to both the Yoruba people of Ogbomoso and the Hausa Community in Sabo, Ogbomoso.

\section{CONCLUSION}

The major factor through which groups establish contact has been through migration. Contact between peoples of diverse ethnic and cultural background have often led to conflicts or integration. Writers have been pre-occupied about inter-ethnic conflicts in Nigeria. As if the whole spectrum of inter-ethnic relations in Nigeria have always been conflictual. The history of inter-group relations in the Nigerian area is abound with case of harmonious inter-ethnic relations. This has been neglected or probably unnoticed by writers. This work has discovered that in spite of the various political crises that had led to inter ethnic conflicts in various parts of Nigeria, the Hausa community in Sabo, Ogbomoso had harmonious inter-ethnic coexistence with their Yoruba hosts in Ogbomoso between 1924-1967. This has been achieved through peaceful trade and commercial relations; the recognition of the Hausa group through the establishment of quarter within the town and establishment of political institution for the Hausa people as well as market officials.

\section{REFERENCES}

Albert, I.O. (N.D.) "The LADA "Racet" in Colonial Yorubaland 1933 - 1950", (Pp.133 - 149), in G. O. Oguntomisin and S. Ademola Ajayi (eds.), Readings in Nigerian History and Culture. Ibadan : Hope Publications.

Albert, I.O. 1994. Urban Migrant Settlements in Nigeria: A Historical Comparison of 'Sabon Garis' in Kano and Ibadan 1893 - 1991. Ph.D. Thesis. Ibadan: University of Ibadan

Cohen A. 1969. Customs and Politics in Urban Africa. A Study of Hausa Migrants in Yoruba Towns. London: Routeledge \& Kogan Paul.

Gbadamosi, T.G.O. 1978. The growth of Islam Among Yoruba 1841 - 1908. London: Longman.

Ikime, O. 1985. "Pre-colonia intergoup relations in Nigeia." A Paper presented at a Conference of the Historical Society of Nigeria, Ibadan, Johnmof

Love Joy, P. (N.D.) Caravan of Kola - The Hausa Kola Trade 1700 - 1900. Zaria: ABU Press

Makinwa, P.K. 1981. Internal Migration and Rural Development in Nigeria. Ibadan: Heinemann, p. 6. 
Mandi Adamu 1978. The Hausa Factor in West African History. Zaria/Ibadan: OUP.

Nnoli O. 1978. Ethnic Politics in Nigeria. Enugu: $4^{\text {th }}$ Dimension

O 'Connel, J. 1967. "The Inevitability of Instability." Journal of Modern African Studes, 5(2): 1.

Onwuejeogwu, M. Angulu 1987. "Indigenous SocioEconomic and Political Organisations and their Relevance to Development in Contemporary Nigeria." Paper presented at the Annual Conference of the Nigerian Anthropological and Sociological Association on Strategies of Authentic Development in Nigeria. University of Ilorin, 30 November - 2 December.

Schererhon, T.A. 1970. Comparative Ethnic Relations: A Frame Work for Theory and Research. New York: Random House
Stanfield J.H. 1996 "Multi-ethnic Societies and Regions." The American Behaviour Scientist, 40(1): 15 .

Tijani, A. 1999. "Ethnic Conflicts in Nigeria: A Case Study of Sagamu/Kano Riots", in R.O. Rom Kalilu (ed.) ELA Journal of African Studies, No. 5 and 6 May \& Oct

Tijani, A. 2002. "A Historical Study of Nupe Migrants in Yorubaland", (Pp. 27-37), in Dele Afolabi (ed.), Reading in the Humanities. Ilesha: Jola Publishers.

Tijani, A 2003. Sabo Communities in Yorubaland, Nigeria (1916 - 1967). Unpublished Ph.D. Thesis, Ilorin: University of Ilorin

Zaruman, W. I. 1998. "Managing Ethnic Conflicts", (P. 3), in W. I. Zaman (ed), The Perimutter Lecture on Ethnic Conflicts: African Conflict "Medicine. London: Lynne Reinner Publishers 